\title{
Promoting Malaysian Government Universities: Potential Students' Views
}

\author{
Ernest Cyril de Run \\ Universiti Malaysia Sarawak \\ Tamil selvi Renganathan \\ Stamford College Kuala Lumpur
}

\begin{abstract}
This study sets out to determine the choice of Malaysian Universities by Form Five and Form Six students in Malaysia. Further to that, respondents were asked of their choice of branding statements and promotion tools for Universities. The top three Universities chosen as first choice were UM, USM and UKM. The top three branding statements overall were excellent teaching staff, excellent resource and safety. The top three promotion tools were teachers, newspapers and parents. Recommendations were made to Universities.
\end{abstract}

Keywords: Branding, Positioning, Promotion, Malaysia, University

\section{Introduction}

Entering into a university would be the aim for majority of the students who have completed their higher secondary education. In Malaysia, in order for students to enter government universities, they need to enter and pass form six. Numbers of students in Form six in 2004 was 87,994 students and in 2005, there were 159,641 students registered in lower six. This is because by passing form six, it is one of the best opportunities in order to enter universities, besides other program like matriculation and diploma in public or private higher institutions (New Straits Time, 2007).

Students will want to enter university with good brand name (Belanger, Mount and Wilson, 2002). Students choose universities based on brand of name of university (Jevons, 2006) and usually universities with good brand name will have higher ranking (Bunzel, 2007) and are seen as more prestigious by students (Belanger, Mount and Wilson, 2002). A good brand name of university for example University of Oxford in United States and University Malaya in Malaysia produce a positive impact of brand name towards students (Gutman and Miaoulis, 2003). Besides that 
students also choose university base on image and reputation regardless of their teaching quality (Huber, 1992).

Today there are a lot of tools available to students in order to obtain information about universities that they are interested before making final decision in which university to enroll (Bunzel, 2007). Examples of the tools are web sites which become the first place students and parents look for information (Gutman and Miaoulis, 2003), newspapers, alumni, and teachers (Bunzel, 2007). There are few studies on students' perception towards branding of Malaysian universities. Most of the studies regarding students' choice are based on Western countries universities (Vaughn et al., 1978; Chapman, 1981; Litten, 1980; Veloutsou, 2005). Thus, this research will focus on perception of form six students in term of the criteria (brand positioning statements) that these students perceive are important in choosing universities and also the promotion tools that they use in obtaining information about universities.

\section{Brief Literature Review}

There were five reports written for the education system in Malaysia before and after independence, which are: Fenn-Wu Statement (1951), Education Ordinance (1952), Razak Statement (1956), Barnes Statement (1960), and Rahman Talib Statement (1960). However, the education system in Malaysia now is based on the Razak Report (1956) (Yahaya, 2003). Malaysia's education system is divided into three levels that are primary, secondary and post-secondary levels (Ching, 2006)

There are five objectives of primary school education that is to master Bahasa Melayu, to master arithmetic skills and use them in daily lives, to master English as the second language, to master scientific and technical skills, to understand and appreciate culture and participate in recreational activity and to develop talent and creativity (Ching, 2006). The primary level of education consists of two types of schools, the national schools and the national-type schools. The national schools use the Malay language as medium of instruction and English is the compulsory subject. Other languages such as Mandarin and Tamil can still be taught to students. Whereas, for the national-type schools, the medium of instruction is either Mandarin or Tamil. However, for the purpose of unity among various ethnic groups in Malaysia, students in national-type school are required to study Malay language and English as compulsory subjects, a suggestion from the Razak Report (1956).

There are three types of schools in the secondary level, academic schools, national religious schools and technical schools (Ching, 2006). In the academic schools, general subjects in art and science streams are offered to the students, plus the vocational and technical subjects which are also included in the curriculum. The national religious schools offer compulsory subjects related to Islamic teachings and also offer general academic subjects to the students same like academic schools. Lastly, the technical schools offer vocational and technical subjects in addition to subjects on general education.

In term of the examination, students in the academic schools and national religious schools are evaluated in the national exam that is Malaysia Certificate of Education (SPM) whereas the technical schools students are required to sit for Malaysia 
Certificate of Education Vocational (SPMV). Both these Malaysia Certificate of Education (SPM) and Malaysia Certificate of Education Vocational (SPMV) are vital examinations in the Malaysian education system because entries to the post secondary level depend on the students' success in these examinations.

Post secondary education or higher education refers to various types of formal postsecondary education institutions (Lee, 1996). There are three programs in this level, the matriculation program, Malaysian Higher School Certificate (STPM) and certificate program. The matriculation program or pre-university studies is a twosemester one-year program conducted by colleges and some local universities for Bumiputera students in order to prepare them for entry to local universities. The Malaysian Higher School Certificate (STPM) is open to all students. This STPM level offer academic, technical and religious subjects. Lastly, the certificate program is a one to two-year program specifically conducted to train students in vocational areas. Education in this Post secondary level is the most important level for students who wish to further their studies in the local universities. This is because entry to local universities is based on the students' result in examinations at this level.

Entries into Malaysia's public universities are based on STPM or MOE. Last year the intake into public universities are based on academic assessment, 90\% and cocurriculum involvement $10 \%$. Through this method of calculation, total of 40,000 students being accepted into the local public universities with 34,951 failing to do so. This is out of a total of 74,967 applicants (Anonymous, nd).

Some time ago, considerations to enter a University included the distance of the university and their hometown (Bunzel, 2007) and there was a lack of information about universities (Kover and Maxwell, 2002). Family members were the main decision makers (Bunzel, 2007). Till the 1970's there was only five public universities. Now there are 20 public universities. Therefore, as more and more public universities emerge, the trend in decision making and information gathering has changed in which brand name of universities plays an important role in influencing students' decision (Jevons, 2006). Asian students are also becoming more selective in choosing an educational institution (Joseph and Joseph, 2000).

The issue of tertiary institution choice criteria has been widely researched (Baird, 1967; Bowers and Pugh, 1972; Murphy, 1981; Hossler, 1995; Joseph and Joseph, 1998). Research done in Australia showed that perspective of students there in choosing university, consider a few factors; type of course, academic reputation of the institution, campus atmosphere, quality of teaching staff and the type of university (Soutar and Turner, 2002).

Furthermore, in this modern era, universities create their own web sites which often are the first place for prospective students or parent to seek for reliable information (Gutman and Miaoulis, 2003). There were three studies focused on the print communications which information to students in the form of prospectuses, booklets and student guides: two studies were conducted in the UK (Mortimer, 1997; Hesketh and Knight, 1999) and one in Australia (Gatfield et al., 1999). Authors of these three studies argued that there was a gap that documents provided for prospective students frequently failed to give sufficient information about academic and practical aspects of the program (Hesketh and Knight, 1999); and that items were frequently missed by 
universities in publications, for example, good teaching, class timetables (Gatfield et al., 1999). Among all types of communication media, mass media advertising is the main source of information to students prior to selecting their institution.

Choice is a concept which is a complex and a process which involves variety of influences that tolerate upon a decision. Early structural models explain choice in the context of institutional, economic and cultural constraints imposed upon choosers whose decisions can be predicted along socio-economic, cultural and ethnic lines (Gambetta, 1996; Roberts, 1984; Ryrie, 1981). This models also can be use to predict and explain students choices of universities that they want to enroll (Maringe, 2006).

One of the difficult problem faces by most Form Five and Form six is that selecting appropriate university and course. Therefore, decision making here can be seen as a problem solving process carry out by these students in the process of making choices. Models of decision making commonly called the purchase behavior of consumers (Maringe, 2006). Chapman (1986) was one of the first to apply buying behavior theory to education sector specifically in selecting an institution or subject of study. The stages include pre-search behavior, search behavior, application search, choice decision and registration.

\section{Research Methodology}

This study sets out to determine Malaysian Form Five and Form Six student's perception towards the various brand names of Malaysian universities. There were 159,641 Form Five and Form Six students in 2008. A calculation of the minimum sample for this study indicated that 264 respondents were required. In order to obtain in-depth understanding, data was collected from a selective convenience sampling of respondents from six different states in Malaysia, namely Selangor, Johor, Penang, Kedah, Negeri Sembilan and Terengganu. Questionnaires were distributed to students in schools and tuition centre in those states.

The questionnaires were divided into two major sections, the first being respondents demographic details. The second part was designed to gather information of respondents perception towards Malaysian universities based on brand position statement and promotion tools. The questionnaires used a five-point Likert scale where $1=$ not important to $5=$ very important. Data collected was analyzed using Frequency and Mean.

\section{Findings}

Out of 270 questionnaires that were distributed, a total of 268 (99.26\%) questionnaires were usable. Respondents demographic profile is detailed in Table 1. 
Table 1: Demographic of Respondents

\begin{tabular}{|l|l|c|c|}
\hline Variables & Frequency & Percent \\
\hline \multirow{3}{*}{ Gender } & Male & 103 & 38.4 \\
\cline { 2 - 4 } & Female & 165 & 61.6 \\
\hline \multirow{5}{*}{ Ethe } & 18 years old & 102 & 38.1 \\
\cline { 2 - 4 } & 19 years old & 166 & 61.9 \\
\hline \multirow{5}{*}{ Latest CGPA } & Malay & 75 & 28.0 \\
\cline { 2 - 4 } & Chinese & 98 & 36.6 \\
\cline { 2 - 4 } & Indian & 95 & 35.4 \\
\hline & $1.00-1.49$ & 19 & 7.1 \\
\cline { 2 - 4 } & $1.50-1.99$ & 12 & 4.5 \\
\cline { 2 - 4 } & $2.00-2.32$ & 26 & 9.7 \\
\cline { 2 - 4 } & $2.33-2.66$ & 42 & 15.7 \\
\cline { 2 - 4 } & $2.67-2.99$ & 55 & 20.5 \\
\cline { 2 - 4 } & $3.00-3.32$ & 71 & 26.5 \\
\cline { 2 - 4 } & $3.33-3.66$ & 23 & 8.6 \\
\cline { 2 - 4 } & $3.67-3.99$ & 3 & 6.3 \\
\cline { 2 - 4 } & 4.00 & 17 & 1.1 \\
\hline
\end{tabular}

The top three Universities chosen as first choice were UM, USM and UKM. Lowest three were UPSI, UTP and UIAM. The top three Universities chosen for second choice were UKM, UPM and UM. Lowest three were UIAM, UTP and UTAR. The top three universities chosen for third choice were UKM, UPM and USM. Lowest three were UTAR, UPSI, UTP and UIAM. The top three universities chosen for fourth choice were UPM, UKM and USM. Lowest three were UiTM, UTP, UTAR and UIAM. See Table 2 for findings.

Table 2: Choice of University

\begin{tabular}{|l|c|c|c|c|}
\hline University & 1st & 2nd & 3rd & 4th \\
\hline Universiti Sains Malaysia & 12.7 & 12.7 & 16.8 & 13.4 \\
\hline Universiti Malaysia Sabah & 4.1 & 4.1 & 4.1 & 6.0 \\
\hline Universiti Malaysia Sarawak & 2.6 & 2.2 & 3.7 & 3.7 \\
\hline Universiti Teknologi Mara & 6.3 & 4.9 & 1.9 & 3.0 \\
\hline Universiti Malaya & 38.4 & 16.8 & 7.1 & 9.3 \\
\hline Universiti Putra Malaysia & 6.3 & 19.8 & 24.3 & 19.0 \\
\hline Universiti Kebangsaan Malaysia & 9.7 & 23.9 & 24.3 & 16.8 \\
\hline Universiti Teknologi Malaysia & 4.9 & 2.6 & 4.5 & 9.3 \\
\hline Universiti Utara Malaysia & 6.7 & 10.1 & 9.0 & 9.0 \\
\hline Universiti Tunku Abdul Rahman & 3.4 & - & 1.5 & 1.1 \\
\hline Universiti Perguruan Sultan Idris & 2.2 & 1.9 & 1.5 & 4.1 \\
\hline Universiti Teknologi Petronas & 1.5 & .4 & .4 & 3.0 \\
\hline Universiti Islam Antarabangsa & 1.1 & .7 & .4 & .4 \\
\hline
\end{tabular}

The top three branding statements overall were excellent teaching staff, excellent resource and safety and the least three were state's natural beauty, multicultural environment and cultural diversity. See Table 3 for findings. 
Table 3: Means for Branding Statements

\begin{tabular}{|l|c|c|}
\hline \multirow{2}{*}{ Branding Positioning Statements } & \multicolumn{2}{|c|}{ Overall } \\
\cline { 2 - 3 } & Mean & S. D \\
\hline Excellent Teaching staff & 4.73 & 0.56 \\
\hline Excellent resource & 4.66 & 0.61 \\
\hline Safety & 4.63 & 0.59 \\
\hline Reasonable tuition fees & 4.62 & 0.7 \\
\hline Excellent physical activity & 4.61 & 0.62 \\
\hline Student support service & 4.56 & 0.66 \\
\hline High standard of education & 4.56 & 0.69 \\
\hline Quality of courses & 4.54 & 0.7 \\
\hline Flexible course & 4.5 & 0.72 \\
\hline Achievement of institution & 4.35 & 0.82 \\
\hline Experience of institution & 4.22 & 0.89 \\
\hline Brand name of institution & 4.17 & 0.94 \\
\hline International recognition & 4.05 & 0.99 \\
\hline Graduate employment prospect & 4 & 0.98 \\
\hline Employer's view of graduates & 3.92 & 1.07 \\
\hline Graduate expected income & 3.82 & 1.09 \\
\hline Stable political environment & 3.71 & 1.22 \\
\hline Hospitality of residents & 3.65 & 1.37 \\
\hline Avenue for religious practice & 3.48 & 1.33 \\
\hline Safety in state & 3.42 & 1.43 \\
\hline Cultural diversity & 3.24 & 1.39 \\
\hline Multicultural environment & 3.22 & 1.43 \\
\hline State's natural beauty & 3.08 & 1.35 \\
\hline
\end{tabular}

The top three promotion tools were teachers, newspapers and parents and the least three were stickers, postcards and bookmarks. See Table 4 for findings. 
Table 4: Means for Promotion Tools

\begin{tabular}{|l|c|c|}
\hline \multirow{2}{*}{ Promotion tools } & \multicolumn{2}{|c|}{ Overall } \\
\cline { 2 - 3 } & Mean & S. D \\
\hline Teachers & 4.57 & 0.82 \\
\hline Newspapers & 4.49 & 0.82 \\
\hline Parents & 4.37 & 0.97 \\
\hline Television & 4.27 & 0.95 \\
\hline Siblings & 4.25 & 1.01 \\
\hline Institution open day & 4.24 & 0.98 \\
\hline Sponsorship & 4.22 & 0.91 \\
\hline Trade show & 4.21 & 0.96 \\
\hline University representatives & 4.1 & 1 \\
\hline Magazines & 4.06 & 1.05 \\
\hline Friends & 4.06 & 1.07 \\
\hline Radio & 3.98 & 1.13 \\
\hline Testimonials & 3.77 & 1.08 \\
\hline Relatives & 3.65 & 1.3 \\
\hline Alumni association & 3.5 & 1.07 \\
\hline Video clips & 3.38 & 1.13 \\
\hline Posters & 3.15 & 1.24 \\
\hline Brochures & 2.98 & 1.37 \\
\hline Photographs & 2.91 & 1.34 \\
\hline Banners & 2.88 & 1.24 \\
\hline Bookmarks & 2.71 & 1.3 \\
\hline Postcards & 2.64 & 1.33 \\
\hline Stickers & 2.6 & 1.28 \\
\hline
\end{tabular}

\section{Discussion}

In Malaysia, a degree seems to be minimum qualification for individual to obtain a good job, to be respected and be successful person (Alfan and Othman, 2005). Therefore, entering into public universities would be aim for almost all. There are only twenty public universities in Malaysia and each year more and more apply for a limited space.

This research showed that UM, UKM, UPM and USM were the top universities preferred by respondents (Table 2). This support past research (Anonymous, 2008) which showed that in 2007 Universiti Malaya was ranked first, followed by Universiti Kebangsaan Malaysia in third and Universiti Putra Malaysia in fourth place. This might be because of brand name of these institutions which is well known among students.

Analysis of frequency towards branding statements showed that excellent teaching staff, excellent resource and safety were the most important attribute or criteria that respondents perceive vital in choosing university. Whereas state's natural beauty, multicultural environment and cultural diversity were the least important attribute (Table 4). These results contradict with study by other researchers Soutar and Turner 
(2002) and Hooley and Lynch (1981) which showed that course suitability and academic reputation were the most important determinants of university choice. Other researcher Joseph and Joseph (2000) showed course and career information as the most important dimension followed by physical aspects and facilities. Nevertheless these are the important criteria for Malaysian students and management of Malaysian universities should take note of these branding statements.

In term of promotion tools that respondents used to gather information about university, it showed that teachers, newspapers and parents were three important determinants that were important and the least were stickers, postcards and bookmarks. This result support the research by Chapman (1981) which stated that parents and high school personnel were significant people that influence the higher institution selection process. Other research by Yamamoto (2006) also supports this study which showed parents have a great influence in the selection process. In that research, also mention that television has highest impact. However, in this research newspaper were the top three determinants. Another research by Price, Matzdrof, Smith \& Agahi (2003) showed Friends opinion were not important in selection process. It is therefore important for management of universities to use the correct promotional tools that carry the appropriate branding statements in order to reach students.

\section{Conclusion}

This research focus on examine Form five and Form six students perception toward branding statements of Malaysian universities and its promotion tools. The top three Universities chosen as first choice were UM, USM and UKM. The top three branding statements overall were excellent teaching staff, excellent resource and safety. The top three promotion tools were teachers, newspapers and parents.

\section{Limitation}

One of the major limitations of this study is that it is limited to Form five and Form six students in five states (Kedah, Pulau Pinang, Selangor, Negeri Sembilan and Johor) in Malaysia. A larger sample size throughout the states of Malaysia and by different ethnic groups would be preferred.

\section{Future Research}

In order to extend this research in future, form five and forms six students in the whole of Malaysia must be taken into account. Further studies should also look at the various ethnic groups views of universities. Aside from that, future studies could also look into the branding statements and promotional tools for private universities in Malaysia.

\section{Reference}

Alfan, E., \& Othman, M. D. (2005), Undergraduate student's performance: The case of university of Malaya. Journal of Quality Assurance in Education, 13(4), $329-43$. 
Anonymous. (2008). Performance of Public universities. Retrieved February 16, 2008, from www.moe.gov.my/english

Anonymous. (nd). Study in Malaysia. Retrieved September 14 2013, from http://www.studymalaysia.com/

Baird, L. (1967), "'The educational tools of college bound youth", American College Testing Program Research Report, Iowa.

Belanger, C., Mount, J. and Wilson, M. (2002), "Institutional image and retention", Tertiary Education and Management, 8 (1), 217-30.

Bowers, T. and Pugh, R. (1972), “A comparison of factors underlying college choice by students and parents", American Educational Research Association Annual Meeting.

Bunzel, D. L. (2007). Universities sell their brands. Journal of Product and Brand Management, 16(2), 152-53.

Chapman, R. (1981), "A model of student college choice", Journal of Higher Education, 52(5), 490-05.

Chapman, R. (1986), "Towards a theory of college selection: a model of college search and choice behavior", Advances in Consumer Research, pp. 246-50.

Ching, P. W. (2006). The Development of Malaysian Economy $\left(6^{\text {th }}\right.$ ed.): Prentice Hall

Gambetta, D. (1996), Were They Pushed or Did They Jump?, Individual Decision Mechanisms in Education, Westview Press, Boulder, Co.

Gatfield, T., Barker, M., \& Graham, P. (1999). Measuring communication impact for university advertising materials. Journal of Corporate Communication, 4(2), 73-79.

Gutman, J., \& Miaoulis, G. (2003). Communicating a quality position in service delivery:An application in higher education. Journal of Managing Service Quality, 13(2), 105-11.

Hesketh, A.J. and Knight, P.T. (1999), "Postgraduates' choice of programme: helping universities to market and postgraduates to choose", Studies in Higher Education, 24 (2), 151-63.

Hooley, G. J. \& Lynch, J. E. (1981), "Modeling the student university choice process through the use of conjoint measurement techniques", European Research, $9(4), 158-70$

Hossler, D. and Foley, E. (1995), "Reducing noise in the college choice process: the use of college guidebooks and rating", New Directions for Institutional Research, 88, 91-107. 
Huber, R. M. (1992), "Why not run a college like a business?", Across the Board, November, 28-32.

Jevons,C. (2006), "Universities: a prime example of branding going wrong”, Journal of Product and Brand Management, 15(7), 466-67

Joseph, M. and Joseph, B. (2000), "Indonesian students' perception of choice criteria in selection of a tertiary institution: strategic implications", The International Journal of Educational Management, 14(1), 40-4.

Joseph, M. and Joseph, B. (1998), "Identifying need of potential students in tertiary education for strategy development", Quality Assurance in Education, 6 (2), 90-6.

Kover, A.J. and Maxwell, S. (2002), "The University in Franeker (1585-1811): a case study in the consumption of history", Journal of Advertising History, 1 (1), special edition.

Lee, M. N. N. (1996). Higher Education, in Jomo K. S and Ng Suew Kiat (eds.), Malaysia's Economic Development, Policy and reform, Petaling Jaya: Pelanduk Publication and MIER

Litten, L. (1980), "'Marketing higher education", Journal of Higher Education, 51 (4), 40-59.

Maringe, F. (2006) University and course choice Implications for positioning, recruitment and Marketing, International Journal of Educational Management, 20 (6), 466-79

Mortimer, K. (1997), "Recruiting overseas students: are their information requirements being satisfied?" Higher Education Quarterly, 51 (3), 225-38.

Murphy, P. (1981), "Consumer buying roles in college choice", College and University, 56 (1), 140-50.

New Straits Time (2007), “Institutions to conduct study on students' performance", New Straits Time, English newspaper (8 August).

Price, I., Matzdorf, L. and Agahi, H. (2003), "The impact of facilities on student choice of university", International Journal of Educational Management, 21 (10), 212-22.

Roberts, K. (1984), School Leavers and Their Prospects: Youth in the Labour Market in the 1980s, Open University Press, Milton Keynes.

Ryrie, A.C. (1981), Routes and Results: A Study of the Later Years of Schooling, Hodder and Stoughton, Sevenoaks.

Soutar, G. and Turner, J. (2002), "Students' preferences for university: a conjoint analysis", The International Journal of Educational Management, 16 (1), 40-5 
Vaughn, R., Oatlik, J. and Hansotia, B. (1978), "Understanding university choice: a multi attribute approach", Advances in Consumer Research, pp. 26-31.

Veloutsou, C., Lewis, J. A., \& Paton, R. A. (2005) Consultation and reliability of information Sources pertaining to university selection, International Journal of Educational Management, 9 (4), 279-91.

Yahaya, A.S. (2003), Perkembangan pendidikan di Malaysia: buku rujukan terkini pendidikan di Malaysia bagi guru, mahasiswa, pelajar maktab dan sekolah, PTS Publication and Distribution, Bentong.

Yamamoto, G.T. (2006). University evaluation-selection: a Turkish case, International Journal of Educational Management, 20(7), 559-69 